\title{
LEGISLATIVE HISTORY OF THE FAIR LABOR STANDARDS ACT
}

\author{
JOHN S. FORSYTHE*
}

\section{I}

The roots of the Federal Fair Labor Standards Act of $193^{8}$ are deep in a movement that extends back over a period of years, ${ }^{1}$ yet it is evident that the closest relationship exists with the wage and hour standards established under the National Industrial Recovery Act. When the N.I.R.A. was invalidated by the Supreme Court the subject of federal betterment of wages and hours was not allowed to become quiescent. President Roosevelt is said to have insisted on the labor standards in the r933 legislation and, after the Schechter case, to have repeatedly deplored their abandonment. ${ }^{2}$ A chance for a bold declaration came in 1936 when the Supreme Court reiterated its stand that wage and hour control was beyond the sphere of state, as well as federal, activity. ${ }^{3}$ This decision paved the way for the plank in the Democratic Party platform of the same year urging national action, by constitutional amendment if need be, to eliminate substandard working zonditions and child labor. After the Democratic victory at the polls in November, there is evidence that the manner of carrying out this pledge was receiving much attention from the Administration ${ }^{4}$ and members of Congress.

The intensity of speculation in this regard increased when the $75^{\text {th }}$ Congress met in January, 1937. Some felt that the drafting of a constitutional amendment was the only method by which the party pledge might be carried out, but in his message to Congress on January 6 , the President stated his general opposition to immediate amendment of the Constitution, and asked instead for an "enlightened view" on social legislation from the judiciary in order that democracy might be made to function successfully. Reports of the President's first press conference of the year indicate that plans were being formulated to "do something" about minimum wages as well as judicial opposition to his program. 5 The coincidence of his statements on these two matters was not properly interpreted in the press at the time, but it serves to illustrate the significant fact, namely, the close tie beween federal labor standards

\footnotetext{
- Member of the graduating class, 1939, Duke University School of Iaw.

${ }^{1}$ See de Vyver, Regulation of Wages and Hours Prior to 1938, supra, p. 323.

${ }^{2}$ N. Y. Times, Jan. Io, IV, p. 6, col. 3.

${ }^{3}$ Morehead v. People ex rel. Tipaldo, 298 U. S. 587.

N. Y. Times, Jan. 4, 1937, p. I8, col. 4 .

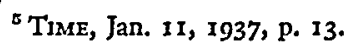


legislation and the President's plan for "reorganization" of the Supreme Court. It was to become clear during the first session of the $75^{\text {th }}$ Congress that each of these plans was being used in the attempt to bring the other into being.

The month of January, 1937, was a period of intense activity behind the scenes so far as wage and hour legislation was concerned. Numerous drafts were being prepared by Administration advisers, Labor Department officials, and even by persons having no public responsibility. General Johnson, of NRA fame, favored a bill making use of the taxing power, while Donald Richberg, his successor, wished to amend the Anti-Trust Laws so as to accomplish the desired end, and make the work under substandard labor conditions an unfair method of competition subject to the jurisdiction of the Federal Trade Commission. ${ }^{6}$

President Roosevelt began his second term of office with conferences with Senator Black of Alabama, chairman of the Senate Committee on Labor, and with Representative Connery of Massachusetts, who held the similar chairmanship in the House. Rumors flew thick and fast as to what was in prospect and, in spite of assurances to the contrary by the President, many felt that a "new NRA" was being prepared which would cover a broad field of trade practices. Then on February 5, I937, President Roosevelt announced his plan for reorganizing the federal judiciary. It was instantly recognized that here was his answer to the problem of getting social legislation held valid. In fact it was announced that a wage and hour bill and other legislation would follow in the wake of the passage of the Court Plan. ${ }^{7}$ The need for control over hours and wages was evidently considered by the President to be one of the strongest weapons available to force passage of the Court Bill. For this reason it was indicated that the legislation would not be submitted until after there had been action on the Court Plan. ${ }^{\mathrm{s}}$

Momentous decisions were being announced by the Supreme Court during this period which were to vitally affect both labor standards legislation and the Court Bill. The Supreme Court reversed its stand on minimum wage legislation ${ }^{9}$ and upheld the Railway Labor Act ${ }^{10}$ and the National Labor Relations Act. ${ }^{11}$ These decisions served to take considerable pressure off of the drive to enact the Court Bill, and as the session wore on without any action on this proposed legislation, the Administration decided to go ahead with the introduction of a wage and hour bill. The provisions of the proposal became known several days before the President's speech on May 24, 1938, calling for its enactment, but the bills introduced into the two houses of Congress by Senator Black and Representative Connery, respectively, deviated from those originally announced in that the basic wage and hour standards were left blank instead of being 40 cents an hour and 40 hours weekly.

The President's message ${ }^{12}$ to Congress asserted the necessity for governmental

\footnotetext{
N. Y. Times, Feb. 3, r937, p. ro, col. 3 .

Id., April 27, p. 1, col. 6.

${ }^{7}$ Id. Feb. 8, I937, p. I, col. 8.

West Coast Hotel Co. v. Parrish, 300 U. S. 379.

${ }^{10}$ Virginian Ry. v. System Federation No. 40, 300 U. S. 515.

11 National Labor Relations Board v. Jones \& Laughlin Steel Corp., 301 U. S. I.

${ }^{12}$ Sen. Rep. 884, 75th Cong. Ist Sess. (1937) I.
} 
control over maximum hours, minimum wages, the evil of child labor and the exploitation of unorganized labor. He stressed the constitutional basis for such legislation in the power of Congress over the channels of commerce and the desirability of barring goods produced under "unfair" standards from these channels. It is interesting to note that the President did not envisage a uniform raising of standards in all industries and for all regions. He stated that as a practical matter there should be "some differentiation between different industries and localities."

Original Bill. On the same day that the President sent his special message to Congress nearly identical ${ }^{13}$ bills, S. 2475 and H. R. 7200, were introduced by Senator Black and Representative Connery. It was to be exactly 13 months and one day from this date before the measure reached the President's desk for signature and only then after having undergone amendment after amendment until practically the only point in common with the original bill was the legislative number. The original bills proposed the creation of a Fair Labor Standards Board of five members to administer the Act and keep goods produced under substandard labor conditions from entering interstate commerce and those conditions themselves from "affecting commerce." Congress was to set statutory minimum wages and maximum hours but the Board would have power to raise or lower these standards. ${ }^{14}$ It is important to note that the purpose of the drafters was not to provide a sudden straight-jacket of wages and hours for all industry. Extreme flexibility was the keynote of this draft. The wages and hours provisions were only to become operative when the Board so ordered, and then only to the specific industries covered by the order. ${ }^{\mathbf{1 5}}$ In addition to these barely non-oppressive wage and hour standards the Board had authority to fix a minimum "fair" wage and a maximum "reasonable" workweek. ${ }^{16}$ Certain statutory objectives were set forth to be used as guides in arriving at those higher standards. However, the Board was restricted to the extent that it could not establish minimum wages of more than $\$ 1200$ a year or 80 cents per hour except for overtime, night and extra-shift work. The Board was authorized, if its members so wished, to appoint advisory committees in the various industries. ${ }^{17}$

Child labor under the age of 16 was prohibited, with power in the Chief of the Children's Bureau to bar the labor of those under 18 in any occupation which he thought "particularly hazardous" or detrimental to their health or well-being. ${ }^{18}$ The child labor provisions were substantially patterned after the Federal Child Labor Law

13 There were two minor points of difference. Foint Hearings before the Senate Committee on Education and Labor and the House Committee on Labor on S. 2475 and H. R. 2700, 75th Cong. Ist Sess. (1937) 44. Hereinafter cited as Hearings.

14 Original Bill, $\S_{4}(\mathrm{c})$. For an explanation of the terminology used in referring to the several bills, see Table of Bills, infra, p. 475.

${ }^{15}$ Assistant Attorney General Robert H. Jackson said in this connection: "Portions of the bill relating to wages and hours would become operative as and when the Board created by the act orders their application. This bill does not plunge the nation headlong into rigid and widespread policy of regulating wages and hours. It permits the building up a body of experience and prevents extension of regulation faster than capacity properly to administer is acquired. The investigations of the Board will also provide the evidence and the findings upon which the Government can rest its argument if the constitutionality of the act is assailed." Hearings, p. 4 .

${ }^{17}$ Original Bill, $\$ 14$.

${ }^{16}$ Original Bill, $\S 5$.

${ }^{18}$ Original Bill, $\$ 2(a)$ (r3). 
declared unconstitutional in Hammer v. Dagenhart. ${ }^{19}$ The use of strikebreakers and labor spies was included in the oppressive labor practices forbidden in this draft. ${ }^{20}$

Hearings. Joint hearings on the proposed legislation were held by the House Committee on Labor and the Senate Committee on Education and Labor from June 2 to June 22, I937. More than twelve hundred pages of testimony was taken from labor leaders, industrialists, trade association representatives, and others. During the hearings on June 15, 1937, William P. Connery, chairman of the House Labor Committee, died, and the leadership for the coming battle in the House passed to Mrs. Mary $\mathrm{T}$. Norton, of New Jersey.

The opening statement at the hearings was made by Assistant Attorney General Robert $\mathrm{H}$. Jackson, who explained the bill section by section and demonstrated the constitutional bases upon which the various sections would be supported. ${ }^{21}$ He likewise took great pains in demonstrating the bill was not "another NRA." John L. Lewis, representing the CIO and the United Mine Workers of America, testified that he was generally in favor of the bill. ${ }^{22}$ He suggested that Congress should set a maximum of 35 hours per week and give the Board power to vary the figure up to 40 or down to 30 as the situation required. Strangely enough, Lewis, and not President Green, of the AFL, was strongly opposed to giving the Board discretionary power to raise wages above 40 cents an hour. He urged the abolition of Section 5 and all other sections pertaining thereto. His reason for so objecting seemed to be the fear that such minimum "fair" wages and maximum "reasonable" hours if fixed by the Board would tend to become actually the maximum wage and the minimum hours. It also seems clear that he felt that it would put a powerful propaganda weapon in the hands of employers if unions saw fit to strike for standards higher than had been set by the Board as "fair" and "reasonable."

William Green, president of the American Federation of Labor, announced that his organization, by action of the executive council, endorsed the proposed Fair Labor

${ }^{10} 247$ U. S. 251 (19r8).

${ }^{20}$ Original Bill, $\$ 2(a)$ (12). This provision was omitted by the Senate Committee on Education and Labor and never revived in subsequent drafts. The committee felt that such matters could best be handled by Amendment of the National Labor Relations Act. SEN. Rep. No. 884, 75th Cong., Ist Sess. (I937) 5.

${ }^{21}$ The several prohibitions of the bill probably incorporate more constitutional theories than any other piece of suggested legislation in the history of the country. The idea was, as Mr. Jackson indicated, to consolidate all hopeful approaches to constitutionality. He stated: "This act combines everything, and is an cffort to take advantage of whatever theories may prevail on the Court at the time that the case is heard. Of course, that results in a good deal of complication." Hearings, p. 54 .

The opinions upon which it was stated that the several sections in the original S. 2475 were based are: $\S 7$ (a) (dissenting opinion by Mr. Justice Holmes in Hammer v. Dagenhart, 247 U. S. 25I (1918)); \$7(b) (Kentucky Whip \& Collar Co. v. Illinois Central R. R., 299 U. S. 334 (1937)); \$7(c) (Wilson v. New, 243 U. S. 332 (1917) and Coronado Coal Co. v. United Mine Workers, 268 U. S. 295 (1925)); \$8(a) (Shreveport Rate Case, Houston, E. \& W. Texas R. R. v. United States, 234 U. S. 342 (1914)); \$8(b) (Dayton-Goose Creek R. Co. v. United States, 263 U. S. 456 (1924)); $\$ 9$ (a) (Federal Trade Commission v. Keppel and Bros., 291 U. S. 304 (1934)); §9(b) (Stafford v. Wallace, 258 U. S. 495 (x927)); §1o(I) (National Labor Relations Board v. Jones \& Laughlin Steel Corp., 30r U. S. I (1937)); \$10(2) (Stafford v. Wallace, 258 U. S. 495 (1937)); §ro(3) (Coronado Coal Co. v. United Mine Workers, 268 U. S. 295 (1925)); \$22(b) Whitfield v. Ohio, 297 U. S. 43 I (1936)). Hearings, pp. 58-62.

${ }^{2}$ Hearings, p. $27 \mathrm{I}$. ${ }^{23}$ Id., pp. $279,285-286$. 
Standards Act of 1937 but wished to offer several perfecting amendments. ${ }^{24}$ These amendments were mainly to strengthen the administrative portions of the act and further protect collective bargaining agreements. ${ }^{25}$ Green stated that the AFL wanted no overlapping between collective bargaining activity and governmental control of wages and hours; that he understood the legislation was merely an attempt to encourage collective bargaining and as collective bargaining expanded, government control should abandon the field. Mr. Green would carry this theory to the extent of refusing to let the Board raise standards reached through collective bargaining even if they were below the minimum standards set by Congress. ${ }^{20}$ Green recommended a basic 40-hour week with Board having power to vary it down to 30 hours. He also recommended a basic 40 cent minimum, but unlike Lewis he favored leaving the power in the Board to raise wages up to 80 cents per hour. ${ }^{27}$ Green also expressly favored a Board of five to administer the act. This is interesting in view of his later position concerning the administrative features. ${ }^{28}$

Sidney Hillman, president of Amalgamated Clothing Workers of America, a CIO union, took an opposite position to Mr. Lewis on the question of whether or not under Section 5 the Board should have power to set up "fair" wages and "reasonable" hours higher than the basic standards set by Congress. ${ }^{29} \mathrm{He}$ wanted the Board to have this discretion. He explained this difference partly on the ground that Mr. Lewis's experience had been with an industry which bargained on a national scale, while his own was in industries such as textiles, garments, and shoes, where collective bargaining cannot cover the whole industry, and the only way to raise standards uniformly is to have it done by the government. Forcing high standards on a few employers at a time would drive those out of business before the rest of the industry could be effectively organized. ${ }^{30}$

Appearing against the bill, George $\mathrm{H}$. Davis, president of the Chamber of Commerce of the United States, criticized it mainly for the uncertainty in future labor costs which it would cause. ${ }^{31}$ Mr. James A. Emery, General Counsel of the National Association of Manufacturers, argued that the bill used an unconstitutional view of the commerce power, and was also an invalid delegation of power. ${ }^{82}$ Mr. Noel Sargent, economist for the same organization, also appeared in opposition to the bill. His most important arguments were that it would raise the cost of living for the farmer, that it would be impossible to administer such a complicated and cumbersome bill in a satisfactory manner, and that it would be an unfair burden on the manufacturer who has foreign competition either here or abroad. ${ }^{33}$ Others appearing against the bill were Guy L. Harrington, National Publishers Association; Arthur Besse, Pres-

${ }^{24}$ Id., p. 21I. The Executive Council of the AFL had been in session when the bills were first introduced and Green had announced that the organization might oppose a wages and hours bill because there was "strong feeling on the part of some against minimum wages for men." N. Y. Times, May 24, 1937, p. $\mathrm{r}, \mathrm{col} .2$.

${ }^{28} I d .$, p. 226; cf. id., p. 227.

${ }^{28}$ See note 46, infra.

${ }^{30} I d$., p. 498.

${ }^{32}$ Id., pp. $623-645$.

${ }^{25}$ Hearings, pp. $221-222$.

${ }^{27}$ Id., pp. 220-221.

${ }^{20}$ Hearings, pp. $945 \cdot 946$.

${ }^{31}$ Id., pp. 935-943.

${ }^{33} I d .$, pp. $645-66_{4}$. 
ident of the National Association of Wood Manufacturers; Samuel Fraser, Assistant Secretary of the International Apple Association; Claudius Murchison, President of the Cotton Textile Institute; John B. Scott, Anthracite Institute; and Benjamin C. Marsh, Executive Secretary of the People's Lobby.

S. 2475 in the Senate. On July 8, 1937, Senator Black, for the Senate Committee on Education and Labor, favorably reported the Fair Labor Standards Act with amendments. In one sense the Senate Committee Bill was even more flexible than the Original Draft, in others not so flexible. No statutory minimum wages or maximum hours were set up. Instead the Board was given power to set these standards. ${ }^{34}$ However, the range of this power had been greatly curtailed from that in the original bill for the minimum wage could not exceed 40 cents an hour and the maximum hours could not be under 40 hours a week. Advisory committees were made mandatory. ${ }^{35}$ The child labor standards were lowered so that children under 16 could be employed in occupations which the Chief of the Children's Bureau found would not interfere with their schooling or be detrimental to their health. Finally a provision was added to quiet the opposition which had developed around the fear that higher wages and lower hours would mean higher production costs which in turn would mean an influx of cheap foreign goods. ${ }^{36}$ This provision gave the Tariff Commission the power to investigate to see if higher tariff rates would be necessary because of increased costs of production. ${ }^{37}$

The bill as reported by the Senate Committee did not reach the floor of the Senate for debate until July 26. There were no particular developments of importance in the debate aside from the open split that developed in the AFL ranks between President Green and certain of the department heads. A move to recommit the bill was given impetus by the fact that the AFL was said to be opposed to the form the bill had taken. Mr. Green denied that the AFL favored recommitment. He stated that the bill did not meet labor's expectations, but that it seemed advisable to pass it in its present form with the hope that satisfactory amendment could be effected in the House. At the same time that this announcement was read to the Senate a statement was also read urging recommittal of the bill because of alleged interference with the operation of the Walsh-Healey Act. This latter statement was signed by John P. Frey and J. W. Williams, heads of the metal and building trades departments in the AFL. ${ }^{38}$ A number of Southern senators attacked the bill, but the statement attracting the most attention was that of Senator E. D. Smith of South Carolina to the effect that it only took 50 cents a day to live reasonably and comfortably in his state. ${ }^{39}$

The Bill passed the Senate on July 3I, x937, by a vote of 52 to 28 . The only outstanding change made on the floor of the Senate was the substitution of the so-called Wheeler-Johnson child labor amendment in place of all the child labor provisions of

\footnotetext{
${ }^{34}$ Senate Committee Bill, $\S_{4}$ (b) and (c).

${ }^{30}$ See Hearings, pp. 75-76.

${ }^{35} I d ., \S \mathrm{I} \mathbf{r}$

${ }^{37}$ Senate Committee Bill, $\S 8(c)$ and (d). (I937).

${ }^{38}$ N. Y. Times, July 30, r937, p. I, col. 6; id., July 31, p. 4, col. 2. See also 8I Cong. Rec. 8192 ${ }^{38}$ N. Y. Times, July 31, I937, p. I, col. 4 .
} 
the Senate Committee Bill.40 This amendment was based on the convict-made goods formula, whereby a state may exclude goods produced under standards lower than those prevailing within the state, which had been severely criticized at the hearings. ${ }^{41}$ It may be that one reason for the relatively easy passage in the Senate was that the opponents of the bill, or of specific provisions of the bill, as in the case of the AFL, had decided it would be better strategy to wait and fight the issues out in the House. The possibility of early adjournment would add to the value of this technique.

First House Committee Bill. Although the prolonged battle over the Court Plan had added to the usual Congressional urge to leave Washington in mid-summer, a group of some thirty members of the House had pledged themselves to fight adjournment until the wage and hour hill was enacted. ${ }^{22}$ On August 6, r937, the Senate bill with amendments of the House Committee on Labor was reported out favorably. The most important change was to replace the Wheeler-Johnson child labor amendment with the child labor provisions in the Senate Committee Bill. ${ }^{43}$ The demands of the AFL for protection of collective bargaining agreements were met to the extent of providing that the Board should not have jurisdiction of wages and hours in occupations where collective bargaining facilities were adequate. It would seem that the bill would have passed the House if it could have been brought to a vote at that time, but the Rules Committee, by a combination of Republicans and Southern Democrats, refused to issue a rule to let the House consider the measure. An attempt was made to get action by calling a Democratic caucus but when it met on August I9, I937, no business could be transacted because a quorum would not answer to their names, and this spelled the doom of the legislation at this session. ${ }^{44}$

Special Session. President Roosevelt issued a call for a special session to convene on November I5 $_{5}$ I937. On October I2, he made a radio address in which he declared that wage and hour legislation would be one of the matters considered at the special session; and in a special message to Congress on November 15, 1937, he pointed out the need for federal wage and hour legislation. ${ }^{45}$

When the session convened, however, it immediately became apparent that the members of the Rules Committee had not changed their views on the subject and that they would refuse to issue a rule to let the House consider the bill. On November 16, I937, Mrs. Norton started a petition to discharge the Rules Committee from further consideration of the matter. At first it did not appear that sufficient names would be secured. For one thing during the summer, more opposition had developed in the ranks of the AFL and President Green had been instructed to consult with

${ }^{10}$ Senate Bill, \$24. This provision had been reported favorably as a separate bill by the Senate Interstate Commerce Committee. N. Y. Times, June 8, 1937, p. 9, col. 3.

${ }^{\star 2}$ See p. 489 , infra, for explanation of the theory of this provision.

${ }^{2}$ N. Y. Times, July 3 , 1937, p. I, col. 4 .

${ }^{4}$ H. R. Rep., No. 1452, 75th Cong., Ist Sess. (1937) 9.

1 This can probably be explained by the fact that many members were not in favor of the legislation at that time for one reason or another and did not want it to be brought from committec, though they would have felt compelled to vote for it if it had been brought to the floor where a vote could have been forced. See 82 Cong. REc. 197 (1937).

${ }^{45}$ N. Y. Times, Dec. 1, p. 22, col. 5 . 
the heads of the various departments of the Federation before issuing any more statements about the wages and hours legislation. The AFL opposition now centered on granting discretionary powers to an administrative board. ${ }^{46}$

In an attempt to meet this AFL opposition the House Labor Committee proposed an amendment placing the administration of the act in a newly created wages and hours division of the Department of Labor with an administrator appointed by the President. This second House Committee Bill differed greatly from former bills. Instead of having a Board initiate moves to set minimum wages and maximum hours with the aid of an advisory committee, the new draft provided that the power should be shifted to wage and hour committees ${ }^{47}$ to be appointed by the administrator. The committee recommendations were binding on the administrator if supported by evidence and based on certain enumerated guides in the statute. Although the House Labor Committee wished to make these numerous amendments to the Bill held by the Rules Committee, it still did not appear that the chance to make amendments of any sort would be given. Some of the group, who had in the previous session tried to prevent adjournment before action on the Bill, now determined to make use of the practical political expedient of trading votes. The strategy was to block the farm program until the Rules Committee relaxed its stranglehold. This tie-up with the vote on the farm bill, in the drive to secure names on the petition, was apparently successful. Representative Jones of Texas, sponsor of the farm legislation, was induced to sign, and sufficient signatures were secured by December 2 to discharge the Rules Committee. Representative Fish of New York proffered a resolution that an investigation be made of the Administration lobbying during this period but it did not receive serious attention. ${ }^{48}$

When it became evident that the House would vote on the Bill the AFL was not satisfied with the changes suggested by the House Labor Committee. A bill drafted at the convention in Denver was brought forward and offered as a substitute bill under the sponsorship of Congressmen Dockweiler and Griswold. ${ }^{49}$ It provided for rigid 40 cent minimum and 40 hour maximum, with an 8-hour day. Since no discretion was necessary to administer these provisions the only enforcement was through the Attorney General. Criminal proceedings were to be brought by the various Federal District Attorneys. After this was defeated by $I_{62}$ to I3I, the AFL threw its weight to have the bill recommitted, which was done on December 17,1937 , by a vote of 216 to 198.50

The combination of conservative Southern Democrats with Republicans and AFL followers explains the vote, although it came as considerable of a surprise after enough names were secured to get the Bill on the floor. Alsop and Kintner in a syndicated column state that the shift of the vote in the Louisiana and New

${ }^{10}$ This is traceable to the attitude taken by the AFL leaders toward the National Labor Relations Board. There had been no previous objection on this point, in fact a board had been specifically approved. See note 27 supra.

${ }^{17}$ Second House Committee Bill, $\$ 4$.

${ }^{48}$ N. Y. Times, Nov. 30, 1937, p. 9, col. x; id., Dec. 3, 1937, p. 1, col. 8.

482 ConG. ReC. I59I (x937). ${ }^{50}$ Id., p. 1835 . 
Jersey delegations was crucial and explain the shift on the basis of the rufled feelings of New Orleans' Mayor Maestri and the desire of Jersey City's Mayor Hague to take a slap at John L. Lewis. ${ }^{51}$ The same dispatch indicates, however, that Lewis did not have a lobby actively working against recommittal. ${ }^{.2}$

Third Session of the 75th Congress. Although the wage and hour bill was quite definitely on the agenda for the Third Session of the $75^{\text {th }}$ Congress, it received very little attention during the early months of that session. Due notice was taken of the defeat of Heflin in the Alabama senatorial election by Lister Hill who, while in the House, had voted for the wage and hour bill. Still, subsequent to this came the defeat of the President's Reorganization Bill by the House and this was widely held to be a personal rebuke to the President and to the New Deal program in general. ${ }^{.3}$ In the light of this it seems quite unlikely that any legislation of the type of the wage and hour bill would have been enacted at that session if it had not been for Senator Pepper's victory in the Florida Democratic Primary. The House Labor Committee had already reported out a new bill but it was resting in its usual pigeon-hole in the Rules Committee. Senator Pepper's victory, after a campaign in which the Bill had been an issue, served to open the floodgates, and when the petition to discharge the Rules Committee was opened for signature the required number of names were secured in two hours and 20 minutes. The favorable poll of the Institute of Public Opinion undoubtedly had its effect also. ${ }^{54}$

The Third Session Bill took a still different approach to the problem of flexibility of standards. This time the administration of the act was to be placed in the Secretary of Labor..$^{55}$ His main duty was to decide if a given industry was in interstate commerce (under standards set up by the statute). If he so found, the wages and hours provisions became automatic and were applicable. No regional differentials were provided. The standards this time were on a scale basis which changed from year to year. ${ }^{56}$ Of course with the rigid standards there was no need of any advisory committees. This bill without substantial amendment was passed by the House on May 24, 314 to 97 .

Before this Third House Committee Bill was introduced Mrs. Norton had appointed a subcommittee of the House Labor Committee under the chairmanship of Representative Ramspeck of Georgia to make a report. Mr. Ramspeck's report, however, was not accepted by the committee. He therefore submitted it to the House as a minority report and asked that it be an amendment. His bill contained some of the provisions of the older bills: A five-man board to administer the act with power to fix minimum wages and maximum hours within the old 40-40 limit. One new thing added was a provision to keep the board from raising the pay more than five cents in any one I2-months period. This was defeated on May 24 by a vote of $\mathrm{r} 39$ to 70 .

Conference Report and Final Enactment. It was necessary now that a conference committee attempt to iron out the differences between the drafts passed by the House

\footnotetext{
${ }^{61}$ N. Y. Times, Dec. 22, x937, p. 20, col. 4. $\quad$ :2 Ibid.

${ }^{63}$ TiMe, April 18, 1938, p. 16.

${ }^{5}$ Third House Committee Bill, \$6.

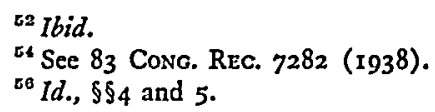


and the Senate. There were rumblings from certain Southern Senators of a filibuster unless the differential, omitted in the Bill passed by the house, be restored. This question of regional differential seems to have been all-important during the period that the conference committee was at work. It is interesting to note that Administrator Andrews, then New York Industrial Commissioner, stated his opposition to a statutory regional differential in a radio address delivered at this time. ${ }^{\mathbf{5 7}}$

The deadlock in the conference was holding up adjournment and it was freely predicted that once again the wage and hour legislation would fail. Senators Ellender and Pepper, members of the conference, at first refused to accede to a statutory wage ever going above 30 cents an hour. ${ }^{58}$ But compromises as to flexibility in attaining minima and the inclusion of a provision which could be construed to allow regional differentials (although expressly disclaiming it) paved the way to agreement in the conference on a completely rewritten bill. This was adopted by the House on June I3 and by the Senate on June I4 with comparatively little debate. The bill received the President's approval on June 25, 1938.

Provisions of the Act. The Act as signed by the President sets up a rigid scale of wages and hours for workers in interstate commerce or who produce goods for such commerce. A statutory minimum of 25 cents is in effect the first year, then a 30-cent minimum is the standard until October, 1945, when the 40-cent wage becomes operative. (Section 6). Unless there is payment of one and one-half times the regular rate of pay covered employees may not be worked in excess of 44 hours the first year, 42 hours the second and 40 after the second. (Section 7). The enforcement of the Act is under the control of a single Administrator in the Department of Labor. Industry committees, appointed by him, may make recommendations which can be made the basis of a wage order setting a minimum wage in excess of the universal rate but not more than 40 cents an hour. (Section 8 ). There are numerous exemptions, some outright, some dependent upon administrative regulation. There may be criminal and injunction proceedings against violators and civil recovery of double damages by workers. (Section I6). Child labor under I6 years of age is prohibited except under certain conditions laid down by the Chief of the Children's Bureau, and may even be eliminated in certain occupations up to 18 years of age (Sections 3 (I) and I2).

This article is divided into two main sections. The first has outlined the broad general legislative history from the introduction of the bill until its signature by the President. This second section attempts to pick out particular features and follow them through the maze of proposals which make up the very complicated legislative history of this particular act. The second section is itself divided into a number of parts selected arbitrarily to bring out the most important provisions as they were developed.

\footnotetext{
${ }^{67}$ N. Y. Times, May 31, 1938, p. 29, col. 4.

${ }^{68}$ N. Y. Times, June 9, I938, p. I, col. I; id., June Io, I938, p. I, col. 8.
} 
In all, ten different bills reached the floor of Congress, all with at least a major change from its predecessor and most of them in the form of amendments substituting an entirely different proposal. Even the structure of the bills was completely changed. The original bill contained five main parts with 30 subsections. The final draft was in a completely different form with Ig sections in no way comparable to the original sections. Of necessity there has been a limitation of the discussion to these ten proposals. There is evidence that many more drafts were written which never got to the floor. ${ }^{59}$

For the sake of convenience the bills are summarized here. The terminology indicated is used throughout the article.

I. Original Bill. Introduced May 24 , 1937 , in the first session of the 75 th Congress. In the Senate it was S. 2475; in the House H. R. 7200.

2. Senate Committee Bill. Introduced into the Senate July 8, 1937, S. 2475, 75th Congress, first Session, Calendar No. 905 .

3. Senate Bill. Passed by the Senate July $3^{\mathrm{r}}$, 1937 , and sent to the House of Representatives, 75th Congress, first session.

4. First House Committee Bill. Senate Bill with amendments added by the House Committee on Labor. Introduced into the House August 6, 1937. S. 2475, $75^{\text {th }}$ Congress, first session, Union Calendar No. 535. This bill did not reach the House floor before the session ended.

5. Second House Committee Bill. Introduced into the House as amendment to the First House Committee Bill December 14, 1937, during the special session. 75th Congress, second session. It was recommitted to the House Labor Committee December 17, 1937 .

6. AFL Bill. This amendment was sponsored by the American Federation of Labor as a substitute for the Second House Committee Bill. It was introduced on December 15 , I937 by Representative Griswold and defeated December 16, x937, 75th Congress, second session.

7. Third House Committee Bill. This was introduced into the House on April 2I, 1938. S. 2475, 75th Congress, third session. Union Calendar No. 804.

8. Ramspeck Bill. This is a minority bill from the House Labor Committee. Introduced May 4, 1938. 75th Congress, third session. This bill had been introduced in the same session of Congress under a different number, H. R. 10538, 75th Congress, third session. It was defeated May 24, I938.

9. House Bill. This is the third house committee bill with amendments added from the floor of the House. Passed by the House May 24, 1938. 75th Congress, third session.

ro. Act. This is the bill rewritten in the conference. Pub. L. No. 718,75 th Congress, third session (June 25, I938). 52 STAт. I060, 29 U. S. C. \$\$201-219 (Supp. 1938).

Although this was one of the most bitterly fought pieces of legislation ever to be enacted by Congress, with the true issues frequently clouded by storms of falsification and propaganda, a calm analysis reveals that there were really only three main points of contention: flexible against rigid wage and hour standards, single administrator against a board to administer the act, and method to be used to enforce the child labor provisions of the act. The detailed analysis to follow is based on this division.

${ }^{58}$ In looking through the files of the House Labor Committee over 25 separate drafts were discovered which had been considered by the Committee, only four of which ever reached the floor. 


\section{(A) Administrative Provisions}

In the ten bills which are being discussed in this article there were no less than five different methods of administering the provisions of the acts. The administrative machinery was naturally closely correlated with the wage and hour provisions and the change in one will partially explain the change in the other.

The original bill ${ }^{60}$ created an independent agency called the Labor Standards Board with five members for staggered terms of five years at salaries of \$ro,000 a year. The members were to be appointed by the President with the advice and consent of the Senate and were eligible for reappointment. In making the appointment the President was to consider industrial and geographical conditions.

Before making a wage order in a given occupation the Board could, "if it considered it necessary or appropriate" 11 appoint an advisory committee to investigate and report upon the fair value of services rendered on the number of hours reasonably suitable to the nature of the work involved, or both. The committee was to be made up of an equal number of persons representing employers and employees in the occupation as well as not more than three persons representing the public, the first two groups being selected as nearly as practicable from lists of names submitted by employers and employees in the occupation. If the committee did not report within 60 days a new committee was to be appointed. The Board was to give the committee all available data on the industry involved, and it could accept or reject in whole or in part the committee report, or appoint a new committee. The Senate Committee on Education and Labor made one important change in the advisory committee by making it mandatory on the Board to appoint an advisory committee before a labor standard order could be issued (it had been optional in the original bill). It should be noted, however, that the committee report was not binding on the Board. ${ }^{62}$

The first important change in the manner of selecting the Board came in the First House Committee bill. There an effort was made to give equal representation by providing that the members should be chosen one from the Northeast, one from the Northwest, one from the Southeast, one from the Southwest and one from the Central part of the United States; and further, one of the members was to be a representative of employers and another one to be a representative of employees. To decentralize the administration as much as possible the House Labor Committee provided that the Board should appoint a director for each state, territory, and the District of Columbia. ${ }^{63}$

One of the focal points of attack on the early drafts of the bill was the administrative provisions establishing the independent Labor Standards Board. During the Ist Session of the 75th Congress the opponents of the bill cried "bureaucracy" at every

${ }^{80} \$ 3$.

62 Senate Committee Bill, §II.
${ }^{01}$ Original Bill, \$14.

${ }^{03}$ First House Committee Bill, $\$ 3(a)$. 
opportunity. When, in the interim between the Ist Session and the Special Session ${ }^{04}$ the American Federation of Labor joined in this cry the pressure became irresistible and it was apparent that some change would be necessary before enough support could be secured to discharge the Rules Committee. ${ }^{65}$ The revision vested the administration of the act in a wage and hour division to be set up in the Department of Labor with an administrator appointed by the President. ${ }^{66}$ Although the administrator was in the Department of Labor he was independent in that his orders were not subject to review by any person in the executive branch of the government.

The most important change, however, was the shift in power from the Administrator, the lineal descendant of the Board, to the advisory committees, which were called wage and hour committees, ${ }^{67}$ and which were to be appointed by the Administrator in any occupation where he found a substantial number of employees employed at wages and hours inconsistent with the minimum standards of living necessary for health, efficiency, and general well-being. Their duty was to recommend minimum wages and maximum hours for that occupation. Furthermore, the Administrator could set minimum wages and maximum hours only after the committee made their recommendation, having no power to set the standards himself although he could reject the committee recommendation and either send it back or appoint a new committee to consider the problem.

Following the suggestion of the Secretary of Labor, ${ }^{68}$ the Administrator and Chief of the Children's Bureau of the Department of Labor ${ }^{60}$ were granted power to utilize and pay for the services of state and local officials charged with the administration of state labor laws. ${ }^{70}$ This is particularly advantageous in situations where intimate knowledge of local conditions is needed such as for the purpose of issuing certificates for child labor or handicapped labor. At the same time it would tend to strengthen the state labor agencies.

The wage and hour bill which the AFL had introduced at the second session of the 75th Congress contained the simplest administrative provisions of all the proposed bills. Because of the rigid standards there was no administrative machinery. Enforcement of the act was in the hands of the Attorney General who was authorized to petition for injunctions in the district courts to enjoin violations of the act. The various United States district attorneys were to be in charge of any criminal prosecutions.

When the Third House Committee Bill appeared it took a fourth approach to the problem. This time the administration of the act was entrusted to the Secretary of

Bะ See p. 470 , supra.

${ }^{65}$ Mrs. Norton announced on the floor during the Special Session that many members had promised to sign the petition if the administration was taken from a five-man board and therefore the labor committee was prepared to offer an amendment which would place the administration in a division of the Department of Labor under an administrator. 82 CoNG. REc. 357 (1937).

${ }^{\circ 6}$ Second House Committec Bill, $\S_{3}(\mathrm{a}), 3(\mathrm{~b})$, and $3(\mathrm{c})$.

${ }^{87}$ Second House Committee Bill, $\$ 4$.

${ }^{68}$ Hearings, p. 184

${ }^{\circ 0}$ See section on child labor, infra, p. 487 .

${ }^{70}$ Second House Committee Bill, $\$ 3$ (b); Act, $\$$ II (b). 
Labor. ${ }^{71}$ However, his only important duty was to determine, after a notice and hearing, whether an industry was in interstate commerce. If he found that it was in interstate commerce his duties were practically over for that automatically caused rigid standards of wages and hours to apply.

The Ramspeck amendment at the $3^{\text {rd }}$ session of the $75^{\text {th }}$ Congress was practically the same as the Senate Bill as far as administrative provisions were concerned. He proposed a five-man Board to administer the act with the aid of an advisory committee in setting wages and hours. ${ }^{72}$

The administrative provisions of the bill passed by the house were substantially the same as those in the Third Committee Bill which had been introduced at that session. ${ }^{73}$

The conference report, presenting a fifth method of administration, was a compromise between the theory of the Senate Bill and that in the House Bill. In many ways it was better than either. A wages and hours division in the department of Labor was created under an Administrator appointed by the President, with the advice and consent of the Senate. An industry committee, descendant of the advisory committees and wage and hour committees, must be appointed by the Administrator in each industry engaged in interstate commerce as soon as practicable. These committees may set, within certain limits, wage standards higher than the rigid standards in the act, thus providing some flexibility.

Investigations and Records: Under the original bill the Board was given broad powers of investigation to gather data regarding wages, hours, and other conditions of employment and their effect on interstate commerce to determine whether persons were violating the act, to aid in enforcing the act, or to gather information for the basis of recommendation of further legislation. ${ }^{74}$ The usual powers were also granted to subpoena witnesses, take evidence etc. The final Act gave much the same powers to the Administrator, industry committees, and Chief of the Children's Bureau. ${ }^{75}$

Very important to the enforcement machinery of the act are the requirements that employers keep certain records and reports to aid in discovering violations. The original bill required employers subject to the act to make and preserve records prescribed by the Board regulation or order as to conditions and practices of employment and to make a certified copy of the records for the Board whenever requested. Board representatives were to be permitted to examine and copy any books or records pertaining to conditions of employment. Employers subject to a labor standard order were required to keep a copy of the order posted in every room where employees subject to the order were employed. ${ }^{76}$ The senate committee bill contained many new regulations as to records, reports, and schedules to be posted in places of employment. Apparently these additions were made at the suggestion of Secretary Perkins who had testified that experience of state labor agencies had found such regulations

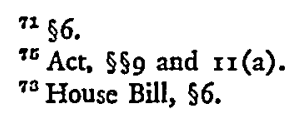

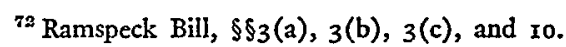

$34 \$ \times 5(a)$.

${ }^{78}$ Original Bill, $\$ 17(a)$. 
necessary to facilitate enforcement. ${ }^{77}$ The Act contains less detailed requirements, being somewhat similar to the original bill. ${ }^{78}$

\section{(B) Wage and Hour Standards}

Probably the most bitter fight in the whole wage and hour legislation developed around the issue of flexible against rigid standards. ${ }^{79}$ Not only were personal, economic, and social viewpoints involved but difficult constitutional issues were encountered. Those in favor of flexible standards pointed out that rigid standards would run into serious due-process problems; those favoring rigid standards contended the flexible standards involved unconstitutional delegation of powers. ${ }^{80}$

The various wage and hour provisions run the gamut from extreme flexibility in the early bills to extreme rigidity in the AFL and House Bills, with a compromise in the conference of low rigid standards tempered by the possibility of wage variations within definite bounds through the flexible machinery of industry committees. ${ }^{81}$

The original bill proposed a somewhat complicated wage and hour schedule centered around the concepts of "oppressive wage,"82 "oppressive workweek," 83 "substandard wage,"84 and "substandard workweek."85

The standards for an oppressive wage and oppressive workweek were to be filled in by Congress. However, even these standards could be varied in either direction by the Board; in case of wages, if necessary "to prevent the depression of general wage levels below those consistent with the maintenance of a minimum standard of living necessary for health and efficiency, without unreasonably curtailing opportunities for employment" or, in case of hours, where the Board found it necessary "considering the physical and economic health, efficiency, and well-being of the employees and the number of persons available for employment, without unreasonably curtailing the earning power of the employees." ${ }^{86}$ But these levels were to be barely

${ }^{77}$ Hearings, p. 185 .

${ }^{78}$ Act, $\$ I I(c)$.

${ }^{70}$ The problem was much more basic than merely a disagreement over flexible or inflexible standards. In the final analysis the argument was one involving different theories of political science. Those in favor of flexible standards believed that the legislation could be best handled by an administrative body of experts who could devote their whole time to the problem. They argued that Congress did not have the time or facilities to intelligently cope with the situation. On the other hand the persons favoring rigid standards argued that Congress could, and should, set standards which would be fair and just to all concerned. The same problem is at the heart of all government through administrative agencies.

${ }^{80}$ Robert $\mathrm{H}$. Jackson pointed out that wage and hour legislation inherently involves these two constitutional problems and of necessity standards must not be set so rigidly that an extremely harsh case can be brought up under the due process clause, while on the other hand flexible standards must have enough legislative guides to stand up under a delegation of powers argument. Hearings, p. 19.

${ }^{81}$ In the discussion of the wage and hour provisions the reader should note that an "order" can only be given after a hearing, while a "regulation" may be issued at the discretion of the administrative agency.

${ }_{82}$ Oppressive wage was a wage lower than....... cents per hour unless another minimum wage standard was established by regulation or order of the Board. Original Bill, \$2(a)(10).

${ }^{83}$ Oppressive workweek was a workweek longer than...... hours per week unless another standard was established by regulation or order of the Board. Original Bill, $\$ 2$ (a)(I I).

84 Substandard wage was a wage lower than a minimum fair wage established by an order of the Board. Original Bill, $\$ 2(a)(16)$.

${ }^{85}$ Substandard workweek was a workweek longer than a maximum reasonable workweek established by an order of the Board. Original Bill, $\S_{2}(a)\left(x_{7}\right)$.

${ }^{80}$ Original Bill, $\$_{4}(\mathrm{c})$ and ${ }_{4}(\mathrm{~d})$. 
nonoppressive, and the Board had authority to set higher standards under Section 5 of the original bill.

When the Board became convinced that "owing to the inadequacy or ineffectiveness of the facilities for collective bargaining, wages lower than a minimum fair wage are paid to employees in any occupation" subject to the act, it could conduct an investigation of the wages paid in such occupation and the value of the services rendered therefor. If the Board found that wages lower than a minimum fair wage were being paid in a substantial part of the occupation and that the establishment of a minimum fair wage would not unreasonably curtail opportunities for employment, the Board could make an order setting a minimum fair wage in that occupation. In determining the minimum fair wage the Board was to consider: (I) the cost of living and all other relevant circumstances affecting the value of the service rendered, (2) such things as would guide a court in a suit for reasonable value of services rendered without a contract as to the amount of the wage to be paid, (3) the wages established for work of comparable character by bona fide collective labor agreements, and (4) wages paid for comparable work by employers who voluntarily maintain fair wage standards in the occupation.

Likewise, under the same conditions, the Board could fix a maximum reasonable workweek where it would not unreasonably curtail the earning power of the employees. In arriving at the maximum reasonable workweek the Board was to consider: (I) the relation of the work to the physical and economic health, efficiency, and well-being of the employees and other relevant circumstances affecting the reasonableness of the period of working time for the work performed; (2) the number of persons available for employment in the occupation to be subject to the workweek order, and also factors (3) and (4) set out to be considered in connection with minimum fair wages. ${ }^{87}$ However, the Board could not set an hourly wage of over eighty cents except for overtime, night, or extra shift work, or one which would yield an annual income of more than $\$ 1,200$; nor could it set a workweek of less than..... hours.

It is not until one examines the broad powers granted to the Board through its authority to issue labor standard orders that the extreme flexibility of this original bill is fully realized. ${ }^{88}$ Each order, which could only be made after notice and hearing to interested parties, had to state the provision or provisions of the act on which it was based, and to define the occupation, the territorial limits thereof, and the class, craft, or industrial unit to which it related. In issuing the order the Board could classify employers, employees, and employments within the occupation according to

\footnotetext{
87 The original bill recognized that differentials could be established but it was not the expectation that they should arise merely because of geographical location of a particular industry. Jackson explained that, "The differential which the Board would embody in an order is not a differential which the Board established; it is the differential which already exists, but which it recognized, because the Board is required to find the value of the services at the point which is under consideration. . . . The Board is authorized to recognize in each community the factors in its life which produce a differential, and to fix that differential into its minimum as collective bargaining will be expected to fix it in its maximum." Hearings, p. 40 .

${ }^{88}$ Original Bill, §12.
} 
localities, population of communities, number of employees, nature and volume of goods produced, and other differentiating circumstances necessary to carry out the act, and to make appropriate provision for different classes of employers, employees, or employment. But it was declared to be the policy of the Board to avoid unnecessary classification. In the case of an order relating to wages, the Board had authority to include such terms and conditions as it considered necessary or appropriate to prevent the established minimum wage becoming the maximum wage and to prevent the discharge or reduction in wages of employees receiving more than the established minimum wage. 89

The bill as it appeared from the Senate committee had undergone some change in its wage and hour provisions. Instead of a fixed standard set by Congress with power to raise it by Board order, the new bill provided that there should be but one set of standards and those should be set by the Board. The space for variation was drastically reduced because the Board could not fix wages higher than 40 cents an hour or hours lower than 40 per week. The concept of "substandard" wages and hours did not again appear. However, in fixing the standards under the Senate Committee Bill the Board was to consider exactly the same conditions that were to have been controlling under the original bill ${ }^{10}$ (and the standards were not to be applied if they would curtail earning power or curtail opportunity for employment). It was declared to be the policy of the Board to reach the maximum wage and minimum hours as quickly as was economically possible. In an effort to quiet the fears of union officials concerning collective bargaining a section was added specifically announcing that nothing in the act was to be construed as interfering or diminishing in any way the right to bargain collectively for standards higher than were set up under the act. ${ }^{.1}$

The Senate retained the wage and hour provisions but added two more factors to be considered in setting minimum wages. Besides the four previously enumerated the Board was to consider (I) discriminatory freight rates, and (2) local economic conditions. ${ }^{92}$

The wage and hour provisions remained substantially the same in the First House Committee Bill but the factors to be considered in fixing the minimum wage were again slightly changed. The provision that discriminatory transportation costs or freight rates were to be considered altered to read "the relative cost of transporting goods from points of production to consuming markets." ${ }^{\text {"93 }}$ An additional consideration was the "differences in units costs of manufacturing occasioned by varying local natural resources, operating conditions, or other factors entering into the cost of production. The Bill provided that the wage and hour regulations should apply to

${ }^{80}$ This attempt to prevent the minimum from becoming the maximum could only be effective as to those employees whose standards were so low that a labor standard order could be issued concerning them. Thus there was nothing to keep an employer from reducing wages of employees outside the coverage of the act. Hearings, pp. 38-39, 6r, 78 .

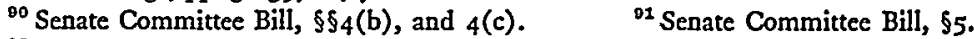

${ }^{82}$ Senator Black announced that these provisions were really contained in the conditions set out in the senate committee bill, therefore they added nothing, merely made it certain that the new factors would be considered. 8I CoNG. Rec. 7892 (I937). ${ }^{\$ 3} \$_{4}(\mathrm{~b})$. 
workers without regard to sex, ${ }^{94}$ and also contained further safeguards for collective bargaining. A labor standard order could issue only if the Board found that existing collective bargaining facilities were inadequate or ineffective or that collective bargaining agreements in that occupation did not cover a substantial portion of the employees. ${ }^{95}$ Nor could the order set a lower wage or higher hours than the minimum wage and maximum hours prevailing for like work in the locality where the order was effective unless the local standards were higher than the Board could set under the statute. ${ }^{96}$ And finally, the minimum wage and maximum hours established in an occupation by collective bargaining were to be prima facie evidence of the appropriate minimum wage or maximum hours to be established for like work. ${ }^{97}$ These are actually further conditions on the issuance of labor standards although not directly in that section of the bill.

When the Second House Committee Bill shifted the authority to set wage and hour standards from the Administrator to the wage and hour committees, it was only natural that the committees should be bound by the same considerations that had guided for the Administrator. In setting up the wage and hour committees the Administrator was directed not to appoint them in occupations where no employees received less than 40 cents an hour or worked more than 40 hours per week..$^{97^{a}}$

The most rigid standards of all were contained in the AFL bill; a minimum wage of 40 cents and a maximum workweek of 40 hours, with no more than 8 hours any one day. ${ }^{98}$ The hours provisions were not to apply in certain cases of emergency.

The bill introduced at the regular session contained a rigid progressive scale which required 25 cents for the first year, 30 cents for the second year, 35 cents for the third year, and 40 cents after the third year.99 Likewise the maximum hour provisions lowered each year from 44 hours the first year, to 42 hours the second year, and 40 hours after the second year, with no more than 8 hours in any one day. ${ }^{100}$ This was the first administration bill which did not leave the way open for differentials and that caused a storm of protest on the floor of the House from some of the Southern representatives, the most vocal of whom was Representative Cox of Georgia. This was the first time that the undercover fight which had been going on over the problem of differentials had been carried to the floor. ${ }^{\mathbf{1 0 1}}$

The Ramspeck amendment contained substantially the same provisions concerning wages and hours as the First House Committee Bill. However, he did introduce a new concept in providing that the Board should calculate "weighted average" minimum wages in a given industry. ${ }^{102}$ The minimum set could not be more than five cents per hour more than this weighted average and wages could not be raised

o\& $\oint_{2}(\mathrm{c})$.

${ }^{00} \$ 5(c)$.

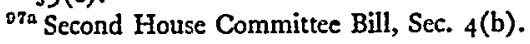

${ }^{20} \S 4$.

${ }^{85}$ First House Committee Bill, $\$ 5(\mathrm{~b})$.

${ }^{07} \S_{5}(\mathrm{~d})$.

$88 \$ 2$. $100 \$ 5$.

${ }^{101}$ But see statement by Mrs. Norton that one reason the bill was recommitted at the Special Session was because it contained differentials. 83 CoNG. Rec. 7275 (1938).

103 The "weighted average" was calculated by taking the total pay roll and dividing by the total number of workers. 
more than five cents in any one I2-months period. ${ }^{103}$ The Board could not fix maximum hours under 40 nor over $4^{8}$ per week except in case of certain plans to employ on a yearly basis. ${ }^{104}$

The conference agreement was a compromise between the other bills. The rigid scale of wages and hours was retained in the milder form of 25 cents for the first year, 30 cents for the next six years, and 40 cents, after the seven year period. Hours were 44 the first year, 42 the second, and after that 40 per week. ${ }^{10,5}$ However, flexibility was provided for wages by establishing industry committees which have power to investigate and recommend minimum wages (not over 40 cents) higher than provided for in the rigid scale. It is the policy of the act to reach this minimum of 40 cents as soon as economically possible and the rigid scale is merely to be certain that at the end of the seven years all industry will have reached that level.108 As soon as practicable the Administrator is to appoint an industry committee for each industry engaged in commerce or in the production of goods for commerce. The members are to equally represent employers, employees and the public, and geographical regions in which the industry is located are to be considered in the choice. From time to time the Administrator is to convene the industry committees to consider the question of minimum wages in the industry it represents. The committee has power to make such classifications within an industry as are necessary to fix for each classification the highest minimum rate which will not substantially curtail employment in the classification, and will not give a competitive advantage to any group in the industry. In determining whether such classifications should be made, in making such classifications, and in determining the minimum wage rates for such classification the industry committee shall consider among other relevant factors the following: ( $\mathrm{I}$ ) "competitive conditions as affected by transportation, living, and production costs; (2) the wages established for work of like or comparable character by collective labor agreements negotiated between employers and employees by representatives of their own choosing; and (3) the wages paid for work of like or comparable character by employers who voluntarily maintain minimum-wage standards in the industry." However, no classification shall be fixed solely on a regional basis. ${ }^{107}$ As in the previous bills it was provided that no classification should be made on the basis of age or sex.

The industry committee is then directed to file a report containing their recommendations with the administrator, who after notice and hearing to interested parties shall by order make the recommendations effective if he finds that they are made in accordance with the above enumerated standards; otherwise he shall disapprove of the recommendations and shall refer the matter to the same committee or to a different committee. He must either accept or reject the recommendation for he has

${ }^{103} \$_{4}(\mathrm{~b})$.

${ }^{204} \S_{4}(\mathrm{c})$.

${ }^{100}$ No eight hour a day maximum was inserted because of a feeling on the part of the conferces that it was, after all, an individual matter for the employees as long as the total hours per week were controlled. 83 CoNg. Rec. 9257 (1938). ${ }^{100}$ Id., p. 9164 .

${ }^{107}$ Congress intended that there might be differentials but they must be based on facts, not on geography. 83 CoNG. REC. 9256-9257 (I938). 
no authority to alter it. Seven years after enactment of the law wage orders become ineffective except under particular circumstances. In making wage orders the Administrator shall define the industries and classifications therein to which they are to apply and shall contain such terms and conditions as the Administrator finds necessary to carry out the purposes of the orders. No order is effective till due notice has been given by publication in the Federal Register.

The final act contained a clause ${ }^{108}$ that the act shall not justify any employer in reducing a wage which is in excess of the minimum required by law; or in raising a workweek which is lower than the maximum hours permitted by law. ${ }^{109}$

Exemptions. In examining the exemption provisions in the various bills the first thing which impresses one is the difference between the way the problem was attacked in the original bill and those which followed it. The original bill had few specific exemptions but placed broad discretionary powers in the Board to make necessary exemptions. As the bill progressed the discretion became more and more narrow and the specific exemptions became larger and larger. Probably most of the specific exemptions enumerated in the final act would have been brought under the original bill; but many exemptions which might have been made under the original bill were not provided for in the final act. Of course in a bill of this kind, the section providing for exemptions is the logical point for pressure groups to point their activity.

There are really three general classes of exemptions to be discussed. The first is the exemptions from all the provisions of the bill; the second is the exemptions from the hours provisions; the last is from wages. ${ }^{110}$

In the original bill persons employed in an executive, administrative, supervisory, or professional capacity or as an agricultural laborer were excluded from the terms of the act. It is important to note that these terms were to be defined by the Board. ${ }^{111}$ By the definition of "employer"112 the United States, any State or political subdivision, or any labor organization (except when acting as an employer) are not included in the act. Small employers were to be exempt from the wage and hour provisions (not child labor) of the original act if the Board so provided by regulation or order. But the Board could bring them under the act if necessary to carry out the act or prevent circumvention of its provisions. ${ }^{113}$ The number of employees which would entitle an employer to this exemption was left blank, to be filled in by Congress. An important condition to this exemption was a provision that the Board had power by regulation or order to determine the method of computing the number of

${ }^{208}$ Act, $\$ 18$.

${ }^{200}$ The clause discussed in note 89 was carried through all the administration bills until the third house committee bill. In that draft there was no provision for labor standard orders as the clause disappeared. The provision added in the final act is much broader, applying to both wages and hours, and also by implication applying to all employees regardless of what wage they receive, or what hours they work. If the conferees had intended it to be construed more narrowly it would seem that they would have made it applicable only when wage orders were issued.

${ }^{110}$ Exemptions from child labor are discussed in the section on that subject.

111 Original Bill, \$2(a)(7).

122 Original Bill, \$2(a)(6).

${ }^{123}$ Original Bill, $\S 6(a)$. 
employees. ${ }^{114}$ Although it was not specifically mentioned, the original bill was not intended to apply to retailers or service trades. ${ }^{115}$

The Board was authorized to provide by regulation or order that employment at wages below the legal minimum, or at hours above the maximum, or both, would not be an unfair labor practice in the following cases: learners and apprentices could be employed at such wages below standard as the Board should prescribe; persons whose earning capacity is impaired by age or physical or mental deficiency or injury could be employed at wages below standard under Board supervision; Board regulation or order could provide for deductions for board, lodging, and other facilities furnished by the employer if the nature of the work is such that the employer is obliged to furnish and the employee to accept such facilities; overtime employment in periods of seasonal or peak activity, or in maintenance, repair, or other emergency work; where, because of the nature and character of employment special treatment is justified. ${ }^{116}$ It is clear from the above that the Board had very broad powers of exemption, in fact it is difficult to think of a case where the Board could not use the last provision as a basis for exemption.

Employers were to be exempt from the hours provisions of the act if they paid for the overtime at the rate of one and one-half times the regular hourly wage rate at which the employees involved were employed.117 However, this exemption was drastically qualified by the fact that the Board could by order withdraw this exemption in any occupation, or could by order set up such standards of wages and hours as were necessary to carry out the purpose or prevent the evasion of the act.

The bill from the Senate Committee contained a number of new exclusions from the act: ${ }^{118}$ employees in local retailing capacity, seamen, railroad employees subject to the Hours of Service Act, persons employed in taking fish, sea foods or sponges, and the definition of agriculture was broadened.110 But apart from these exclusions the terms of the senate committee bill were substantially the same concerning exemptions with the exception that the provision for exempting small employers was not included.

An attempt was made to replace this exemption by amendment from the Senate floor ${ }^{120}$ but the amendment was rejected. ${ }^{121}$ The Senate Bill included new exclusions

${ }^{114}$ This was to prevent evasion by cutting large businesses into small units. Hearings, p. 49-50. It was assumed at the hearings that the number of employees would be somewhere betwcen 10 and 20.

${ }^{115}$ Hearings, p. 35.

${ }^{117}$ Original Bill, $\$ 6(\mathrm{~b})$.

${ }^{116}$ Original Bill, $\$ 6(c)$.

${ }^{118}$ Senate Committee Bill, $\$ 2(a)(7)$.

${ }^{110}$ It now included: farming in all its branches, cultivation and tillage of the soil, dairying, forestry, horticulture, market grading, cultivation and growing of fruits, vegetables, nuts, nursery products, ferns, flowers, bulbs, livestock, bees, and poultry, or any other agricultural or horticultural commodity, any practice ordinarily performed by a farmer, and finally it included the definition contained in subsection (g) of section 15 of the Agricultural Marketing Act, approved June 15, 1929, as amended.

120 8I CoNG. Rec. 7888 (1937).

121 Apparently the committee did not have a very pronounced view either for or against the amendment. One strong point in favor of the exemption was that it made the administrative task much casicr for by far the greater number of all employers employ less than ten persons, and yet their total cmployecs are relatively insignificant when compared with the total employees who would come under the act. It was also argued that the high standards were likely to drive many small employers out of business and thus concentrate industry into fewer hands. On the other side it was claimed that the small employers 
from the hours provisions of the act. These were (I) employees of any common carrier by motor vehicle subject to the maximum hours provisons of the Motor Carrier Act of 1935 , (2) air transport employees subject to title II of the Railroad Labor Act of 1936 , (3) employees of express companies subject to the provisions of the latter act. ${ }^{122}$ A fourth exclusion was made (but from both wages and hours), by broadening the meaning of agriculture to include delivery to market as an incident to farming operations. ${ }^{123}$

Indirectly the meaning of agriculture was broadened in still another manner, by making a definition of "person employed in agriculture" who was excluded from the act. ${ }^{124}$ As that term was used to refer to fresh fruits or vegetables, it included persons employed within the "area of production" engaged in preparing, packing, or storing such fresh fruits or vegetables in their raw or natural state. ${ }^{125}$

Numerous exemptions were made from the hours provisions. They included persons employed in connection with ginning or bailing cotton, canning or packing of fish, sea food, sponges, picking, canning, or processing of fruits or vegetables, processig of beets, cane, and maple into sugar and syrup when the services of the person were of a seasonal nature. ${ }^{126}$ Further exemptions from hours were made in case of employees in plants located in dairy production areas in which milk, cream or butter fat are received, shipped, or manufactured if operated by a cooperative association as defined in the Farm Credit Act of $1933,{ }^{127}$ and in the case of employees engaged in processing or packing perishable agricultural products during the harvest season. ${ }^{\mathbf{1 2 8}}$

The most important changes made by the House Labor Committee concerned the exclusion of "outside salesmen" from the act, ${ }^{129}$ a specific amendment that independent contractors and their employees engaged in transporting farm products from farm to market were not included in the definition of "person employed in agricul-

would furnish unfair and cutthroat competition. Most of the opposition to the exemption naturally came from big business. 8 I CoNG. REc. 7864 (I937).

${ }_{123}$ These amendments were accepted by the committee in conformance with their policy not to put employees under the jurisdiction of two administrative agencies. Apparently action had been taken in these occupations since the committee had drafted their amendment. 81 CoNG. REc. 7875 (r937).

${ }_{123}$ This was accepted to clarify the act, the purpose being to make it clear that the exemption included all work done on a farm as long as it was incidental to agricultural purposes. 8I CoNG. REc. 7888 (I937).

${ }^{124}$ Senate Bill, $\$ 2(a)(19)$.

${ }^{125}$ This amendment was introduced by Senator Schwellenbach specifically to protect the small apple grower in his state who had to go to a central unit to get his crop washed and sorted according to Department of Agriculture rules. The large grower could afford to own his own equipment and thus the operation for him would be part of agriculture. 81 Cong. Rec. 7876 (1937).

The concept of "area of production" was intended to keep the exemption from applying to large central cold storage and packing houses. However, Senator Schwellenbach, in answer to a direct question, admitted that he couldn't define the term and said that the definition would have to be left up to the Board. 8I Cong. Rec. 7879 (1937).

${ }^{230}$ Senate Bill, $\S_{4}(\mathrm{c})$. The senate committee, because of the difficulty of legislatively drawing the line for seasonal production had given broad discretion to the Board to make seasonal exemptions. Sec. $6(\mathrm{~b})$ of the Senate Committec Bill and Senate Bill. Therefore these specific exemptions did nothing more than make certain what the Board could have done if necessary. But in making the exemptions specific Congress left the way open for chiselers to evade the act.

${ }^{127}$ The definition was changed to that of Section 15 of the Agricultural Marketing Act by $\$ 4(c)$ of the First House Committee Bill.
${ }^{128}$ Senate Bill, $5_{4}(c)$.

$$
{ }^{120} \$ 2(a)(7) .
$$


ture" (and thus came under the act), ${ }^{130}$ further cotton exemptions from hours, this time exempting those employed in ginning, compressing and storing cotton, or processing cottonseed ${ }^{131}$ where employment was seasonal, also employees working during the hours from midnight to 6 A.M. in occupations not requiring continuous process operation (i.e., the "graveyard" shift) should be paid time and a half for their work. Women and children were forbidden to work during those hours. ${ }^{132}$

The exemptions and exclusions remained substantially the same in the amendment sent in by the committee at the special session.

A number of new exemptions were added in the Third House Committee Bill, on the floor of the house, and by the conference committee. They will be discussed together, in the form they appeared in the final act.

Some of the new exemptions from both the wages and hours provisions of the Act were: ${ }^{133}$ any employee engaged in any retail or service establishment the greater part of whose selling or servicing is in intrastate commerce; ${ }^{134}$ any employee employed in connection with the publication of a weekly or semi-weekly newspaper of less than 3,000 circulation the major part of which is within the county where the paper was printed and published; ${ }^{\mathbf{1 3 5}}$ any employee of a street, suburban, or interurban railway, or local trolley or motor bus carrier; ${ }^{136}$ and the definition of agriculture was further broadened, this time with the express intent to exempt everything agricultural. As one senator said, "The definition seems to be all-inclusive, and we tried to make it so."137

Employers were to be exempted from the hours provisions (but not wages) ${ }^{138}$ without paying extra for time above the maximum of the act if their employees were employed under a collective bargaining agreement (certified as bona fide by the National Labor Relations Board) which provided (a) that no employee shall work more than rooo hours during any period of twenty-six consecutive weeks, ${ }^{130}$ or (b) more than 2000 hours during any fifty-two consecutive weeks. ${ }^{140}$ Also the ad-

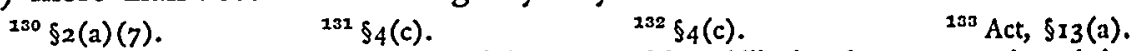

${ }^{134}$ It had been stated by the supporters of the wage and hour bills that they were not intended to apply to retail or service establishments (see Hearings, p. 35), but this amendment was inserted to make certain that none would be included. 83 Cong. Rec. $7437-7438$ ( 1938 ).

${ }^{136}$ The main argument in favor of the amendment was that the only effect of the act on such papers would be to force them to stop their out-of-state circulation, which is usually small, consisting mainly of home town folks who have moved away. Then it was also argued that the small weekly did not have an organization which would lend itself to such standards, an example of which was the typical society editor who collects items in her spare time. 82 Cong. Rec. I810 (1937).

${ }^{238}$ This exemption was to provide for the few cases where such businesses would come under the act (lines running interstate from cities on or near state borders). Such occupations have peak times in morning and evening so that the hours are difficult to regulate. Also it was known that they are generally strongly unionized and get relatively high wages. 83 CoNG. Rec. 7444-7445 (1938).

${ }_{137} 83$ Cong. Rec. 9163 (1938). ${ }^{138}$ Act $\$ 7$ (b).

${ }^{230}$ This provision was to take care of certain special industries with peculiar conditions such as certain lumbering and mining projects where men have to be sent to isolated sections for periods of time, after which they return to civilization. However, while they are working the men desire, and need, to work long hours for there is generally nothing else to do, and they take the jobs in the first place with the intention of working long hours for a short period. 83 CoNG. Rec. 9257 (1938).

${ }_{140}$ This takes care of the employer who has worked out some scheme of annual employment in which the hours may fluctuate considerably. 83 CoNG. REc. 9257 (1938). Representative Barton of New York had introduced a similar provision from the floor, but it had been rejected. 83 Covo. Rec. 7442 (1938). 
ministrator could exempt employers for not more than fourteen weeks in the aggregate in any calendar year in an industry found to be seasonal. ${ }^{141}$ The above three exemptions only applied to the extent of 12 hours in any workday, or $5^{6}$ hours in any workweek and over that wages had to be paid at the usual overtime rate under the act.

Some specific exemptions from the hours provisions were made in certain industries which for special reasons required long hours, as in the first processing of milk; while the aggregate $I_{4}$ week exemption was specifically applied to certain seasonal occupations, particularly pertaining to agriculture. ${ }^{142}$

(C) Chitd Labor

From the very beginning the supporters of child labor legislation (which, incidentally, seemed to include practically all members of Congress) divided into two distinct groups. One group favored the administration method of enforcement, to prohibit the interstate transportation of goods produced by child labor, and the other favored the so-called Johnson-Wheeler amendment based on the prison-made goods theory. ${ }^{143}$ The Johnson-Wheeler amendment was substituted in the Senate for the administration child labor provisions by a vote of 57 to $28^{144}$ but it was subsequently removed by the House Labor Committee and all efforts of its House proponents, led by Representative Martin of Colorado, to reinsert it were unsuccessful. The attack of the Johnson-Wheeler group did, however, cause certain amendments to be added by the House Labor Committee but the basic philosophy remained unchanged.

The original bill defined "oppressive child labor"145 as the employment of any children under the age of I6; however, the Chief of the Children's Bureau of the Department of Labor could by the affirmative action of an order or regulation raise the age level to $\mathrm{I} 8^{146}$ in employments which he found to be particularly hazardous for children or detrimental to their health or well-being.

The Senate Committee lowered these standards by granting the Chief of the Children's Bureau power to permit employment of children under 16 in occupations which the Chief of the Children's Bureau should find would not interfere with their schooling or be detrimental to their health. This broad power to exempt children under the age of 16 drew the fire of the advocates of the Wheeler-Johnson amendment in spite of the fact that Senator Black explained on the Senate floor that the provision was only intended to apply during the vacation months when children

${ }^{161}$ It should be noted that this is an "aggregate" of fourteen weeks and it was not intended that the work need be done in consecutive weeks. 83 Cong. Rec. 9r64 (1938).

$16297(\mathrm{c})$.

${ }^{163}$ The reason the child labor section was included with the wage and hour legislation instead of forming a separate act was because of the feeling that it had a better chance to be declared constitutional as an integral part of general legislation intended to remove the burden of unfair labor practices on the free flow of interstate commerce. Alone, child labor may not be a very great burden, but when considered with the other factors, it has a better chance of surviving attack in the courts. Hearings, pp. I-16.

144 81 CoNG. REc. 795I (1937).

${ }^{140}$ It should be noted that there is no requirement for a hearing before the Chief of the Children's Bureau can issue an "order." Compare with note 8I supra. 
were not in school. In the face of this continued criticism the House Labor Committee accepted an amendment at the special session to limit the power to exempt to children between $\mathrm{I}_{4}$ and $16 . .^{147}$

Another important change was made by the Senate Committee Bill in exempting children employed in agriculture and those employed by "a parent or a person standing in place of a parent."148 The exemption in cases of parents was removed in part by amendment from the floor during the special session to prohibit parents and those standing in place of a parent from employing children under I6 in manufacturing or mining. ${ }^{149}$ It was explained that this was to prevent certain types of industrial work such as tiff mining where the parent might be tempted to employ his own children. ${ }^{150}$

The exemption in case of agriculture was narrowed considerably in the conference bill by a provision that it would only apply when children were not legally required to be in school. ${ }^{151}$ This would seem to leave a way open for states to aid in protection of child labor by high compulsory school ages. ${ }^{152}$ It must be remembered, however, that this standard is not as rigid as it seems on its face for most states have legal excuses for failure to attend school, and one of the commonest of these is the need to work.

A further exemption was inserted on the floor during the special session to exclude child actors engaged in the production of motion pictures. ${ }^{153}$ This exemption was not included in the third house committee bill but was again inserted from the floor in the regular session and this time included children in theatrical productions. ${ }^{154}$

As early as the Senate Committee Bill the Board was directed to utilize the Chief of the Children's Bureau for all investigations and inspections with respect to the employment of minors ${ }^{15 \overline{5}}$ and to bring all actions to enjoin oppressive child labor practices. ${ }^{156}$ This provision was enlarged in the Third House Committee Bill to place all child labor provisions under the administration of the Chief of the Children's Bureau. ${ }^{157}$ In the conference bill the Chief's authority to bring injunction suits was limited because he had to act in this capacity under the direction and control of the Attorney General. ${ }^{158}$

14782 Cong. Rec. 169 I (1937).

${ }^{148}$ Senate Committee Bill, $\$ 2(2)$ (10). $\quad 24082$ CoNG. Rec. I693 (1937).

15082 CONG. Rec. I822 (1937). A "person in place of a parent" included only those actually in the legal position of a parent. 82 CoNG. Rec. I694 (1937).

${ }^{151}$ Act, $\$ \mathrm{I}_{3}(\mathrm{c})$.

${ }^{152}$ It is true that violation of the compulsory school law would be an offense against the state in any case but this extra federal sanction should make evasion much more difficult particularly since the $\mathrm{cm}$ ployer would be the one to suffer. The section has more meaning when it is realized that seven states have a compulsory school age of 18 ; seven of $17 ; 31$ and the District of Columbia have 16; and only threc states have under I6.-See testimony of Miss Katherine F. Lenroot, Chief of Children's Bureau of the Department of Labor, Hearings, p. 385 .

${ }_{153} 82$ CoNG. Rec. 1789 (1937).

${ }^{104}$ Members of the house did not feel that child actors were really within the group which child labor legislation was intended to benefit. 83 CoNG. Rec. 7441 (r938).

${ }^{155}$ Senate Committee Bill, \$15(b). $\quad{ }_{150}$ Senate Committee Bill, \$12.

157 §IO(c).

${ }^{168} \$ 12(b)$. 
The original bill prohibited the interstate shipment of goods on which child labor had been used. ${ }^{159}$ This was changed slightly in the Senate Committee Bill which carried a separate provision prohibiting the interstate shipment of goods which had been produced in an establishment in the United States in or about which within thirty days prior to removal any oppressive child labor had been used. ${ }^{160}$ However, this provision was not to go into effect till I20 days after enactment.

One of the outstanding provisions of the administration child labor scheme was a clause providing that employers should not be guilty of violating the child labor law if the children they employed had a certificate issued under a regulation of the children's bureau certifying that the employee was above the oppressive child labor age, regardless of their true age. ${ }^{161}$ This certificate requirement was intended to keep children from entering into employment illegally and protect the employer who was bona fine trying to observe the law. It was claimed that the JohnsonWheeler amendment was purely penal and only operated after the child labor law had been violated.

The Johnson-Wheeler amendment ${ }^{162}$ took three approaches to the child labor problem: (I) it prohibited interstate shipment of goods produced by child labor; (2) it used the prison-made goods theory of the Ashurst-Summers Convict Goods Act upheld in the Kentucky Whip and Collar case to prohibit transportation of goods produced wholly or in part by child labor into states for use there in violation of the law of that state; and (3) it required labeling of goods produced by child labor. The advocates of this method of enforcement pointed out that it had an advantage over the administration plan in that it directly challenged the decision in Hammer $v$. Dagenhart by its first prohibition, while at the same time it had an alternative method in the convict-made goods approach if the other should be found to be unconstitutional. On the other hand the convict-goods approach was severely criticized by many child labor experts ${ }^{163}$ on the ground that it would be extremely complicated law to administer (convict-goods are made in relatively few places); another objection being that it would require new legislation in practically all states to make it effective, while the approach of the administration through requiring certificates fitted in with most of the state laws. ${ }^{184}$ Another distinct advantage of the administration proposal was that the federal government could utilize the trained state child labor agencies to help control the issuance of certificates as had been done so successfully under the Federal Child Labor Act of 1916.

From the foregoing analysis it is obvious that few legislative enactments in our history have had such a stormy career and assumed so many different aspects within

$$
{ }^{200} \$ 7 .
$$

${ }^{102}$ Senate Committee Bill, $\delta_{2}(a)(x 0)$.

${ }^{100}$ See $\S 23(e)$.

${ }^{182}$ Senate Bill, $\$ 24$.

${ }^{103}$ See testimony of Mr. Courtenay Dinwiddie, General Secretary, National Child Labor Committee, Hearings, pp. 396-403; and Mrs. Larue Brown, representing a group of national women's organizations, Hearings, pp. 389-394.

${ }_{104}$ Mrs. Norton stated on the floor that 43 of 48 states already have the certificate form of child labor law. 82 Cong. Rec. 1783 (1937). 
a comparatively short period of time as has this Act. The history of the Act affords invaluable material to the student of the legislative process in a democracy. In spite of trials and tribulations it is believed that the provisions finally made law are better than those of the original bill-even though admitted weaknesses remain. If great flexibility and wide administrative discretion have been eliminated in favor of more rigid standards, it should be remembered that, while the original characteristics would have permitted the accomplishment of much good beyond the scope of the present Act, they also contain in themselves the seed of many undesirable results and in the absence of an almost super-human job of administration might have done considerable harm to the cause they were designed to serve. 